\title{
Nicole Cazauran, Le langage «biblien» des devisants de "L'Heptaméron"
}

\section{Filippo Fassina}

\section{(2) OpenEdition}

\section{Journals}

\section{Edizione digitale}

URL: http://journals.openedition.org/studifrancesi/6579

DOI: 10.4000/studifrancesi.6579

ISSN: 2421-5856

\section{Editore}

Rosenberg \& Sellier

\section{Edizione cartacea}

Data di pubblicazione: 1 septembre 2010

Paginazione: 349

ISSN: 0039-2944

\section{Notizia bibliografica digitale}

Filippo Fassina, «Nicole Cazauran, Le langage «biblien» des devisants de "L'Heptaméron"», Studi Francesi [Online], 161 (LIV | II) | 2010, online dal 30 novembre 2015, consultato il 13 janvier 2021. URL: http:// journals.openedition.org/studifrancesi/6579 ; DOI: https://doi.org/10.4000/studifrancesi.6579

Questo documento è stato generato automaticamente il 13 janvier 2021.

\section{(a) $\odot \Theta$}

Studi Francesi è distribuita con Licenza Creative Commons Attribuzione - Non commerciale - Non opere derivate 4.0 Internazionale. 


\title{
Nicole Cazauran, Le langage «biblien» des devisants de "L'Heptaméron"
}

\author{
Filippo Fassina
}

\section{NOTIZIA}

NICOLE CAZAURAN, Le langage «biblien» des devisants de "L'Heptaméron", «Bibliothèque d'Humanisme et Renaissance», LXX, 2 (2008), pp. 281-299.

1 L'A. si pone il problema di analizzare le citazioni bibliche di cui è costellato l'Heptameron di Marguerite de Navarre, al fine di riuscire a identificare da quale edizione delle Sacre Scritture la regina attingesse il materiale inserito nella sua opera. $\mathrm{Al}$ di là delle semplici riprese lessicali - peraltro numerosissime -, ciò che realmente interessa è comprendere l'origine delle citazioni e delle parafrasi vere e proprie messe in bocca ai personaggi dell'Heptameron anche all'interno di contesti prettamente mondani. Dato per certo che Marguerite non conosceva il latino in modo approfondito, risulta, in primo luogo, innegabile il debito nei confronti della versione francese di Lefèvre d'Etaples, suo protetto. Tuttavia, il presente studio evidenzia la molteplicità di fonti bibliche delle quali l'autrice dell'Heptameron sarebbe debitrice, a partire dalla Bible historiale complétée, redatta nel xIV secolo, stampata nel 1495 e utilizzata dallo stesso Lefèvre. Anche la Vulgata, scritta in un latino accessibile, è annoverata fra le versioni della Bibbia in possesso della regina e poteva rappresentare senza dubbio una fonte preziosa per le citazioni. Infine, l'A. osserva che, nella vita di Marguerite de Navarre, trovava grande spazio la liturgia pressoché quotidiana e, attraverso di essa, gli echi biblici sarebbero entrati nel patrimonio di conoscenze della regina in maniera del tutto naturale. Da notare un ricchissimo repertorio di referenze bibliche e liturgiche che permettono una catalogazione dettagliata dei passi scritturali citati o parafrasati nell'Heptameron. 